\title{
Rozwój rynku robotów przemysłowych w Polsce i na świecie
}

\section{World and Polish industrial robots market evolution}

\section{Streszczenie}

W artykule przedstawiono rozwój rynku robotyki przemysłowej w kraju i na świecie. Omówiono zalety i podstawowe obszary zastosowania robotów przemysłowych, a także zwrócono uwagę na główne kierunki rozwoju tej branży. Przeanalizowano dane statystyczne dotyczące wielkości sprzedaży robotów przemysłowych w różnych krajach świata, w tym w Polsce.

\section{Wstęp}

W wyniku przemian zachodzących na globalnym rynku wytwórcy z różnych branż przemysłowych zmuszeni są zwiększać asortyment produkcji i jakość wyrobów, obniżając jednocześnie koszty ich wytwarzania. Szczególnie w krajach wysoko rozwiniętych wykonywanie manualnie prostych i powtarzalnych operacji przestaje być opłacalne, dlatego firmy coraz chętniej inwestują w robotyzację.

Robotyzacja to jeden z głównych kierunków rozwoju gospodarki w krajach uprzemysłowionych, w tym również w Polsce. Roboty wykorzystywane są w bardzo różnych aplikacjach, a liczba wdrażanych w naszym kraju stanowisk w ostatnich kilku latach szybko rosła. Dekoniunktura gospodarcza, która w 2009 r. objęła gospodarkę światową, bardzo znacząco wpłynęła również na rynek robotów, przyczyniając się do istotnego spadku sprzedaży tych urządzeń.

Wśród robotów przemysłowych bardzo ważną grupę stanowią roboty przeznaczone do procesów spawalniczych. Szacuje się, że stanowią one ok. 10 $\div 20 \%$ wszystkich przemysłowych zastosowań robotów. Najpowszechniej robotyzacja stosowana jest w procesach spawania elektrodą topliwą w osłonie gazu (MIG/MAG) w produkcji wielkoseryjnej. Proces ten wymaga odpowiedniej wydajności, wysokiej precyzji i jakości produktu

Dr inż. Tomasz Pfeifer - Instytut Spawalnictwa, Gliwice.

\section{Abstract}

Evolution of robotics in Poland and all over the world has been presented. It has been discussed advantages and main fields of industrial robots application, as well as the direction of development of this industrial branch. The statistical data concerning the amount of sold robots in different parts of the world and in Poland have been analyzed. finalnego, którym często są podzespoły wpływające na bezpieczeństwo użytkowania maszyn i urządzeń. Nowoczesne stanowiska zrobotyzowane wyposażone są w najnowsze rozwiązania, umożliwiające zwiększenie wydajności pracy, szybkości komunikacji pomiędzy robotem a urządzeniami peryferyjnymi oraz jakości procesu spawania.

W artykule przedstawiono zmiany ilościowe i jakościowe, zachodzące na rynku robotów przemysłowych, ze szczególnym uwzględnieniem ich wykorzystania w krajach europejskich, w tym w Polsce.

\section{Robotyzacja - zalety, podstawowe obszary zastosowania oraz kierunki rozwoju}

Roboty przemysłowe, zgodnie z definicją, to urządzenia do automatycznej manipulacji z możliwością wykonywania ruchów względem kilku osi. Zaopatrzone są w narzędzia lub chwytaki i skonstruowane do zastosowań w przemyśle. Chociaż początki robotyki sięgają wręcz kilkuset lat wstecz, era robotyki przemysłowej rozpoczęła się całkiem niedawno, bo w 1961 r. Wtedy w zakładach General Motors w New Jersey pracę rozpoczął robot Unimate, którego koncepcję opracował w latach 50. zeszłego wieku George Devon [1]. Założona przez niego wraz z Josephem Engelbergiem firma Unimation była pierwszym na świecie producentem robotów. Opracowane przez tę firmę urządzenie przenosiło odlewy 
ciśnieniowe z wytwarzającej je maszyny, a następnie spawało do ram samochodów.

Najważniejsze czynniki wskazywane przez polskich dostawców robotów, skłaniające firmy do inwestycji w te urządzenia, to [1]:

- redukcja kosztów produkcji - dotyczy różnych kosztów, w tym związanych z zastąpieniem personelu, ale też wynikających z mniejszego zużycia surowców czy minimalizacji liczby wadliwych produktów,

- poprawa jakości i wydajności produkcji,

- możliwość pracy w wymagających aplikacjach, np. w przemyśle spożywczym lub w trudnych warunkach środowiskowych,

- poprawa powtarzalności produkcji,

- zwiększenie elastyczności wytwarzania - roboty umożliwiają reorganizację procesów produkcyjnych bez konieczności wymiany sprzętu,

- lepsza przewidywalność i możliwość planowania wydajności produkcyjnej zakładu,

- zastąpienie personelu, np. ze względu na braki kadrowe, szkodliwe warunki.

Korzyści z robotyzacji produkcji są duże, a wykorzystanie robotów obejmuje coraz więcej branż, w których wcześniej za niezbędne uznawano wykonywanie niektórych czynności ręcznie lub stosowanie maszyn specjalnych. Niestety jednak robotyzacja nie jest tania. Koszt zakupu robota wynosi ok. 100 tys. euro, co często zwiększone jest nawet kilkakrotnie przez konieczność wykorzystania dodatkowego osprzętu czy przebudowę części linii technologicznej, co stanowi znaczący koszt inwestycyjny. Pomimo że może on zwrócić się w niedługim czasie, nawet po dwóch latach, początkowa wartość inwestycji jest uznawana często za znaczącą.

Robotyka przemysłowa w Polsce i na świecie związana jest z kilkoma rynkami i grupami aplikacji. Pod kątem zastosowań, do najczęstszych zastosowań robotów należą: przenoszenie, pakowanie i paletyzacja, montaż, spawanie i zgrzewanie. Istotnymi obszarami ich zastosowań są także malowanie i mycie. Kolejność taka obowiązuje również w przypadku zastosowań w naszym kraju, co przedstawione zostało na rysunku 1 [1].

Rodzaje aplikacji są bardzo często ściśle związane z branżami, w których stosowane są roboty.

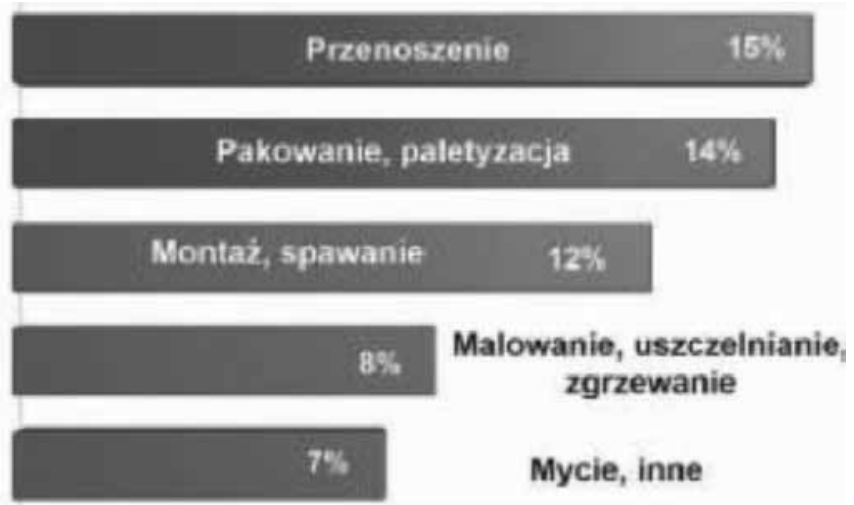

Rys. 1. Zastosowanie robotów przemysłowych w Polsce [1]

Fig. 1. Application of industrial robots in Poland [1]

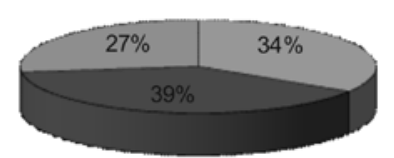

QDuże (ud żwig pow. $100 \mathrm{~kg}$

aŚrednie (udzwig od 6 do $100 \mathrm{~kg}$ )

aMale (udżwig do $6 \mathrm{~kg}$ )

Rys. 2. Udział robotów o różnym udźwigu w całkowitej sprzedaży w Polsce [1]

Fig. 2. Participation of robots of varying capacity in the total sales in Poland [1]

Przykładowo spawanie i zgrzewanie to zastosowania typowe w przemyśle motoryzacyjnym i metalowym, natomiast pakowanie i paletyzacja - w branży spożywczej, FMCG (branża produktów codziennego użytku), przy produkcji materiałów budowlanych i innych. Roboty stosuje się też często w elektronice (montaż precyzyjny), w produkcji różnych elementów (malowanie, nakładanie kleju, nakładanie uszczelek), wytwórstwie mebli, tworzyw sztucznych i w metalurgii. Głównymi klientami firm oferujących roboty przemysłowe są w Polsce są oddziały międzynarodowych koncernów oraz duże i średnie polskie zakłady przemysłowe. Robotami zainteresowane są też coraz częściej mniejsze firmy, jednak rynek traktować można jako mocno rozproszony. W kraju najwięcej sprzedaje się robotów o średnim udźwigu - od kilku do 100 kg. Drugie w kolejności są roboty duże, a ostatnie - wersje najmniejsze, o udźwigu poniżej 6 kg (rys. 2).

W ostatnim przypadku często stosowane są wersje SCARA (akronim z ang. Selective Compliant Articulated Robot for Assembly), które wykorzystywane są przede wszystkim do montażu elementów oraz do ich szybkiego przenoszenia - np. w przemyśle spożywczym czy elektronice. Omawiając sektory rynku, warto zwrócić uwagę na to, jaki wpływ na zmiany w zastosowaniach robotów miał kryzys gospodarczy. W ostatnich latach Polska stała się jednym z ważniejszych krajów produkcji części samochodowych i pojazdów, w latach 2005-2008 roczne dostawy robotów wzrosły kilkakrotnie. Oprócz inwestycji w przemyśle samochodowym, roboty trafiały m.in. do branży elektromechanicznej, elektronicznej, AGD i spożywczej oraz opakowaniowej. Przełom lat 2008-2009 okazał się szczególnie niekorzystny dla największego z rynków zbytu dla robotów, a więc motoryzacji. Był to dla dostawców robotów bardzo trudny okres, nie tylko w Polsce, ale i na świecie, co wymusiło poszukiwanie i rozwijanie nowych rynków zbytu. Obecnie za najbardziej przyszłościową uznaje się branżę spożywczą, w której roboty stosowane są coraz częściej na różnych etapach procesów produkcyjnych. Dostawcy szukają zamówień również w innych branżach, które zaczynają bardzo szybko się rozwijać. Bardzo ważnym rynkiem staje się dla nich także branża fotowoltaiczna (solarna), gdzie zachodzi konieczność przenoszenia i montażu elementów ogniw słonecznych. W tym przypadku nie dotyczy to jednak w dużym stopniu Polski, gdyż głównym rynkiem są Niemcy.

Robotyka jest jedną $z$ najbardziej dynamicznie rozwijających się dziedzin techniki. Same roboty wymagają zastosowania nowoczesnych rozwiązań 
konstrukcyjnych, gdyż sa to urządzenia, które nie tylko muszą wykonywać ruchy o bardzo dużej precyzji i powtarzalności, ale pracują przez wiele lat, często w trudnych warunkach środowiskowych. Według specjalistów z branży, główne kierunki rozwoju robotyki oraz najnowsze trendy $w$ tej dziedzinie są następujące:

- rozwój technologii widzenia maszynowego - prawdopodobnie najważniejszy z trendów w robotyce, gdyż zastosowanie systemów wizyjnych umożliwia użycie robotów w zupełnie nowych aplikacjach lub uproszczenie już istniejących,

- rozpoznawanie nacisku/siły,

- polepszanie parametrów robotów, takich jak: udźwig, zasięg, dokładność i szybkość działania,

- rozwój układów i technologii bezpieczeństwa związanych z robotami,

- rozwój bezprzewodowych paneli operatorskich do robotów,

- możliwość komunikacji sieciowej i zdalnej diagnostyki (np. przez internet),

- rozwój robotów sześcioosiowych mogących wykonywać precyzyjne ruchy,

- integracja kontrolerów robotów w ramach platform sterowania,

- wprowadzanie robotów do pracy w strefach Ex oraz z prowadzeniem wszystkich przewodów podłączeniowych w korpusie (w tym integracja podajnika drutu w korpusie robotów spawalniczych),

- rozwój nowoczesnych aplikacji spawania (bezodpryskowego, niskoenergetycznego itp.),

- rozwój oprogramowania projektowego i symulacyjnego, gdzie wykorzystywane są algorytmy umożliwiające dokładną kontrolę przyspieszeń i całego ruchu, jaki wykonuje ramię robota.

\section{Światowy rynek robotów - dane statystyczne}

Sprzedaż robotów wzrastała od dłuższego czasu o kilka, kilkanaście procent rocznie, a w ostatnich latach na tym rynku zachodzą również istotne zmiany wśród odbiorców tych maszyn. Tempo rozwoju branży można szacować na podstawie dostępnych danych statystycznych oraz przybliżonych prognoz w tych gałęziach przemysłu i dziedzinach, gdzie roboty znajdują zastosowanie obecnie lub znajdą je w przyszłości [2]. Rynek robotyki opisywany jest w różnych raportach, w tym „World Robotics”, który przygotowywany jest co roku przez IFR Statistical Department pod egida VDMA Robotics + Automation [2]. Raport oraz publikacje są również źródłem większości informacji przedstawianych w artykule [1, 2].

Od momentu pojawienia się robotów przemysłowych w zastosowaniach komercyjnych, czyli mniej więcej od końca lat 60. zeszłego wieku, określana jest przybliżona liczba sprzedawanych co roku jednostek tego typu. Przyjmując, że okres serwisowania i pracy jednego urządzenia wynosi od 12 do 15 lat, całkowitą liczbę działających w 2007 r. robotów oszacowano na ok. milion sztuk. Przewiduje się, że do końca 2012 r. ich liczba wzrośnie o ok. 300 tys. W tablicy I przedstawiono liczbę robotów przemysłowych działających w różnych regionach świata.

Największy udział w rynku robotyki ma sprzedaż robotów przemysłowych. Lata 2000-2008 były dla dostawców robotów wyjątkowo sprzyjające. Roczna sprzedaż robotów osiągnęła w 2005 r. rekordową wartość 125 tys. szt., a w kolejnych trzech latach utrzymywała się na poziomie ok. 115 tys. szt. (dane za IFR - International Federation of Robotics) [1]. W tym okresie największym rynkiem dla robotów były kraje azjatyckie (średnio ok. 60 tys. robotów rocznie), następnie Europa (35 tys.) i USA (ok. 18 tys.). Podane liczby dotyczą 2008 r. i pochodzą z opracowania World Robotics z 2009 r. [1]. W latach 2005-2008 następował również niewielki spadek liczby robotów sprzedawanych w Azji i USA, natomiast do rosnących rynków zaliczyć można było m.in. Europę. Przełomowy okazał się 2008 r. w Niemczech, na największym rynku robotów w Europie, sprzedaż wzrosła wtedy do rekordowej liczby 15,2 tys. jednostek, jednak w części innych krajów m.in. we Włoszech, sprzedaż robotów spadła. Z kolei kraje Europy Środkowej i Wschodniej zwiększyły łącznie popyt na roboty o $22 \%$, natomiast Polska - aż o 78\% [1]. Szacunkowe dane dotyczące sprzedaży robotów w krajach europejskich w 2006 r. przedstawiono na rysunku 3 [2].

Jesienią 2008 r. wzrost sprzedaży został zatrzymany i nastąpiło załamanie koniunktury, które w skali europejskiej miało niespotykaną dotychczas wielkość. Powołując się na najnowsze szacunki IFR, stwierdzić można, że w 2009 r. sprzedano globalnie ok. 57 tys. robotów, co oznacza aż $50 \%$ spadek w stosunku do roku poprzedniego. Łączne obroty robotyki i automatyki spadły w 2009 r. w Niemczech o 34\%, co pod

Tablica I. Liczba robotów przemysłowych działających w różnych regionach świata (w tys. szt.) [2]

Table I. Number of industrial robots operating in various regions of the world (in thous. pc) [2]

\begin{tabular}{|l|r|r|r|r|}
\hline \multicolumn{1}{|c|}{ Kraj } & 2005 & 2006 & $\begin{array}{r}2007 \\
\text { (szacun- } \\
\text { kowo) }\end{array}$ & $\begin{array}{c}2010 \\
\text { (progno- } \\
\text { za) }\end{array}$ \\
\hline Ameryka & 143,6 & 154,6 & 167,1 & 209,0 \\
\hline Kanada, USA, Meksyk & 139,9 & 170,7 & 162,4 & 200,9 \\
\hline $\begin{array}{l}\text { Ameryka Południowa } \\
\text { i Środkowa }\end{array}$ & 3,6 & 3,9 & 4,7 & 8,1 \\
\hline Azja & 481,6 & 479 & 500,5 & 579,9 \\
\hline Japonia & 373,4 & 351,6 & 355,0 & 362,9 \\
\hline Korea Południowa & 61,5 & 68,4 & 73,6 & 94,0 \\
\hline Chiny & 11,5 & 17,3 & 23,9 & 47,0 \\
\hline Indie & 1,0 & 1,9 & 3,5 & 14,1 \\
\hline Europa & 296,9 & 315,6 & 329,8 & 380,0 \\
\hline Niemcy & 126,3 & 132,5 & 137,9 & 147,4 \\
\hline Włochy & 56,2 & 60,0 & 63,8 & 72,0 \\
\hline $\begin{array}{l}\text { Europa Środkowa } \\
\text { i Wschodnia }\end{array}$ & 9,4 & 10,7 & \multicolumn{2}{|c|}{ brak danych } \\
\hline Afryka & 0,6 & 1 & 1,7 & 4,4 \\
\hline Sumarycznie & 922,8 & 950,9 & 999,1 & 1173,3 \\
\hline
\end{tabular}




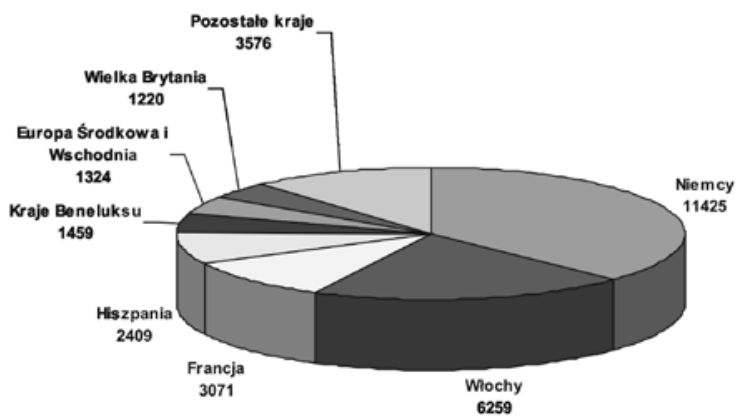

Rys. 3. Liczba robotów sprzedanych w Europie w 2006 r. [2] Fig. 3. Number of sold robots in Europe in 2006 [2]

względem wartości obrotów odpowiadało poziomowi z 2002 r. [1]. Popyt na roboty zmniejszył się w znacznym stopniu szczególnie ze strony przemysłu motoryzacyjnego, gumowego oraz tworzyw sztucznych, a spadków tych nie udało się zrównoważyć przez zwiększenie sprzedaży robotów do innych gałęzi przemysłu.

W ostatnim okresie zauważyć jednak można poprawę na rynku, która zaczęła się pod koniec 2009 r. Zwiększa się stopniowo liczba zamówień, jak też, co potwierdzają niemieckie organizacje branżowe, rośnie liczba zapytań o roboty, która przez poprzednie 12 miesięcy była wyjątkowo niska [1]. W latach 2010-2012 prognozowane jest stopniowe ożywienie, przy czym pod koniec tego okresu możliwy jest powrót do wielkości rynku znanego z lat 2007 i 2008. Dobre tempo rozwoju branży zależy jednak od utrzymania się ogólnego wzrostu w gospodarce, dla tego należy je traktować raczej w kategoriach możliwej prognozy. Powołując się ponownie na szacunki rozwoju największego w Europie rynku automatyki i robotyki - wartość tej niemieckiej branży może wzrosnąć w tym roku o ok. 5\%, do 6,4 mld euro. Popyt powinien pochodzić z różnych sektorów przemysłu: sektora tworzyw sztucznych i gumowego, metalowego i budowy maszyn, spożywczego i opakowaniowego oraz elektronicznego i solarnego. Jeżeli chodzi o globalny rynek robotyki, wg danych organizacji UNEC (United Nations Economic Comission) oraz IFR, wartość tej branży w perspektywie długoterminowej może sięgnąć aż 51 mld dolarów (do 2025 r.) [1]. Szacunki te nie uwzględniają sprzedaży robotów do zastosowań wojskowych, która, wg niektórych analiz, może być znacząca w porównaniu z wartością rynku standardowych robotów przemysłowych.

W celu oszacowania stopnia robotyzacji danego regionu stosowane są różne wskaźniki. Jednym z nich jest tzw. gęstość robotyzacji (robot density), określana jako liczba robotów przemysłowych przypadających na 10000 osób zatrudnionych w zakładach przemysłowych [2]. W latach 2001-2006 zatrudnienie w przemyśle nieznacznie spadło, natomiast liczba instalowanych robotów wzrosła. Na pierwszym miejscu

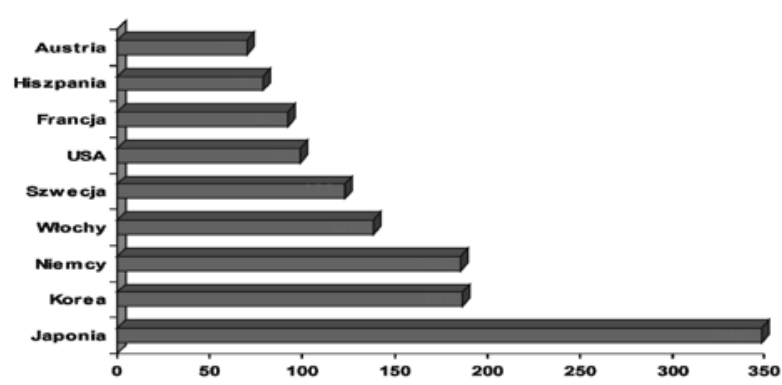

Rys. 4. Liczba robotów przypadająca na 10000 pracowników w wybranych krajach w 2006 r. [2]

Fig. 4. Number of robots per 10000 inhabitants in selected country in 2006 [2]

pod względem gęstości robotyzacji była Japonia z 349 robotami, kolejna - Korea Południowa ze 187 robotami na 10000 zatrudnionych w przemyśle. W Europie na początku 2007 r. najwyższą gęstością robotyzacji charakteryzowały się Niemcy, gdzie wynosiła ona 186 , kolejnymi krajami były Włochy, Szwecja i Finlandia. Kraje Europy Środkowej i Wschodniej charakteryzowały się gęstościami poniżej 40 [2]. Dane dotyczące gęstości robotyzacji w wybranych państwach świata w 2006 r. przedstawiono na rysunku 4 [2].

Pomimo istotnych różnic $\mathrm{w}$ stopniu robotyzacji w rożnych krajach europejskich należy podkreślić, że kilka z nich charakteryzuje się znacznie większą gęstością robotyzacji niż Stany Zjednoczone, gdzie wynosi ona 99. Wiodącą rolę w zwiększaniu liczby robotów w przemyśle pełni sektor motoryzacyjny, dla którego gęstość robotyzacji w wybranych krajach wynosi odpowiednio: Japonia - 1820, Włochy - 1630, Niemcy -1220 , Francja - 1160 i USA - 830. Jest to najbardziej zrobotyzowany sektor, w którym jeden robot przypada średnio na 10 pracowników.

\section{Rozwój rynku robotów przemysłowych w Polsce}

Polski sektor robotyki należy cały czas, pomimo wieloletniej obecności na nim czołowych dostawców tych maszyn, do rynków wschodzących, których potencjał wzrostowy jest duży. O dobrych perspektywach dla działających w Polsce firm dostarczających roboty świadczy m.in. wskaźnik gęstości robotów, który jest standardowym w branży miernikiem rozpowszechnienia robotów w poszczególnych krajach. W Polsce jego wartość to jedynie 10 .

Biorąc z kolei pod uwagę liczbę dostarczanych w Europie robotów, w 2008 r. w Polsce wdrożono ok. 900 szt. tych maszyn (wg World Robotics, 2009), czyli więcej niż w Czechach, Austrii, Turcji czy Szwajcarii [1]. Więcej robotów przemysłowych uruchomiono 


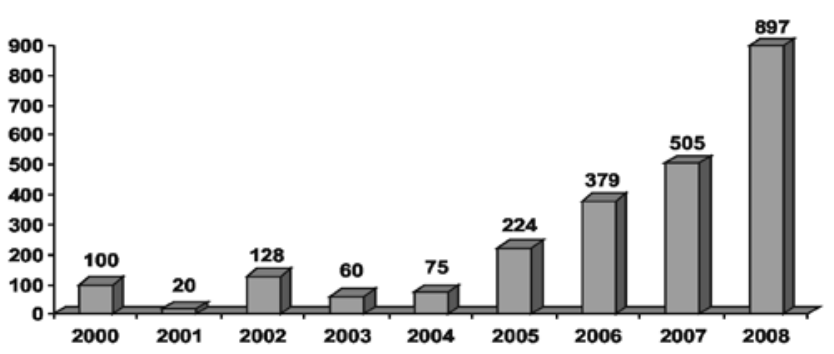

Rys. 5. Szacunkowa roczna sprzedaż robotów przemysłowych w Polsce [1]

Fig. 5. Estimated yearly sales of industrial robots in Poland [1]

m.in. w Wielkiej Brytanii, Szwecji, Hiszpanii i Francji (po ponad 2 tys.), we Włoszech (5 tys.) i Niemczech (aż 15 tys. jednostek) [1]. Porównanie to jest jednak mniej miarodajne ze względu na różne wielkości wymienionych krajów i lepiej jest posługiwać się w tym przypadku wskaźnikiem gęstości robotyzacji. Ogólnie można oszacować liczbę działających w Polsce robotów przemysłowych na ok. $2700 \div 3000$ szt.

Na początku 2008 r. polski rynek rozwijał się w tempie dwucyfrowym - średnie wzrosty sprzedaży dostawców robotów w Polsce odnotowane w 2007 r. wyniosły aż 45\%. Równie dobry okazał się 2008 r., kiedy szacunkowa roczna podaż robotów przemysłowych w Polsce wyniosła ok. 900 szt. (wg World Robotics) (rys. 5) [1].
Występowanie trendu wzrostowego w branży robotów w latach 2003-2008 potwierdzają również informacje czołowych dostawców, dotyczące liczby maszyn sprzedanych w tym okresie. Przedstawiciele ankietowanych firm zadeklarowali, że od 2003 r. łącznie sprzedali lub wdrożyli do produkcji 1358 robotów i stanowisk zrobotyzowanych [1]. Niemal 400 $z$ nich to samodzielne roboty. Obecne dane dotyczące liczby sprzedawanych i instalowanych w naszym kraju robotów można traktować jako dotychczasowy rekord, gdyż przez wiele lat, szczególnie przed wstąpieniem Polski do Unii Europejskiej, sprzedaż roczna była o rząd wielkości mniejsza. Pomimo globalnej recesji rynek polski cechował się dobrą koniunkturą. $Z$ przedstawionej $w$ raporcie grupy firm [1], dwudziestu ich przedstawicieli ujawniło wyniki sprzedaży (liczbę wdrożeń) robotów w latach 2008 i 2009 . Średnie wartości wyniosły 15,9 i 17,5 robota odpowiednio dla 2008 i 2009 r., co dało tym firmom wyniki: 318 wdrożonych maszyn 3 lata temu i 350 w 2009 r. Porównując te liczby z ogólnymi trendami na świecie i w Europie, rynek polski wydaje się być w dobrej kondycji, a popyt na roboty, pomimo globalnej dekoniunktury, jest cały czas wysoki. Sądzić można, że w uzyskaniu takich rezultatów dużą rolę odegrały firmy krajowe, które zajmują się dostarczaniem robotów i tworzeniem aplikacji z tymi maszynami. Specjaliści szacują, że wartość polskiego rynku robotów przemysłowych wynosi ok. $200 \mathrm{mln}$ zł [1].

\section{Podsumowanie}

Boom inwestycyjny w okresie 2004-2005, szczególnie w przemyśle motoryzacyjnym, był wyjątkowo korzystny dla producentów robotów. W kolejnych latach sprzedaż w tym sektorze zaczęła maleć na całym świecie, jednak znacząco wzrosło zapotrzebowanie w innych gałęziach przemysłu i będzie ono nadal stymulowało rozwój rynku robotów przemysłowych w kolejnych latach. Powinno się to przełożyć na wzrost inwestycji w granicach $2 \div 15 \%$ rocznie w zależności od regionu [2]. Coraz więcej firm, które nie będą przenosić swoich zakładów produkcyjnych do krajów o tańszej sile roboczej, będzie inwestowało w robotyzację linii produkcyjnych. Można też przewidywać, że coraz więcej robotów sprzedawanych będzie do krajów, których znaczenie na rynku globalnym rośnie. Dotyczy to m.in. Chin, Indii, Brazylii, Meksyku, a w Europie - Turcji, Rosji oraz krajów Europy Środkowej i Wschodniej, w tym Polski. Istotna staje się robotyzacja niewielkich zakładów produkcyjnych.

Zakup urządzeń takich jak roboty ma na celu nie tylko zatrzymanie produkcji w krajach rozwiniętych, ale także zwiększenie jakości produkowanych wyrobów. Pomimo że robotyzacja linii produkcyjnych wymaga ich odpowiedniego zmodernizowania lub zaprojektowania, znacznie poprawia się elastyczność i ciągłość produkcji. Często roboty zastępują też ludzi tam, gdzie wykonywana praca jest niebezpieczna i uciążliwa.

\section{Literatura}

[1] Piątek Z.: Robotyka przemysłowa w Polsce i na świecie - sytuacja na rynku po kryzysie, Automatyka, Podzespoły, Aplikacje $\mathrm{nr} 5 / 2010$.
[2] Możaryn J., Piątek Z.: Rynek robotyki przemysłowej bez tajemnic, Automatyka, Podzespoły, Aplikacje nr 12/2008. 